\title{
THE LEGAL ISTINBÂTH OF IBNU QAYYIM AL-JAUZIYAH IN THE TERMS OF MEDICATION AND HEALTH
}

\author{
Suansar Khatib \\ State Institute for Islamic Studies (IAIN) Bengkulu, Indonesia \\ J. Raden Fatah Pagar Dewa Bengkulu \\ E-mail: suansar.khatib@gmail.com
}

\begin{abstract}
The problem concern in this research is how the method of legal istinbâth of Ibn Qayyim al-Jauziyah about medication and health and its relevance with modern theory. This is normative legal research with library research methods, in the form of character studies. The source of the primary material is al-ThibbalNabawi, supported by secondary materials, al-Dâ'u wa al-Dâwa', and other relevant materials. Data analysis employed content analysis techniques, the material contained in the text was elaborated by comprehending the contents, then interpreted to obtain the legal istinbâth method regarding the method of medication and health. The results of this study showed that the method of legal istinbâth of Ibnu Qayyim al-Jauziyah in terms of medications, is guided by dilâlah 'ibârah or ibârat nash, namely the Quran, Yûnus [10]: 57, Al-Isra' [17]: 82, and clarified by the hadith of the Prophet Muhammad PBUH. While the method of legal istinbâth of Ibn Qayyim al-Jauziyah in health issues was refering to dilâlah 'ibârah or ibârat nash, Al-Maidah [5]: 6, Al-'Araf [7]: 31, and made clear by the hadith. In terms of modern medication and health, the theory of therapy related to the process of medical action, is by maintaining body health through preventive action and expelling dangerous substances within the body.
\end{abstract}

Keywords: Ibn Qayyim al-Jauziyah; legal istinbâth; medication; health.

\begin{abstract}
Abstrak: Fokus permasalahan dalam penelitian ini adalah bagaimana metode istinbâth hukum Ibnu Qayyim alJauziyah tentang pengobatan dan kesehatan?, dan bagaimana relevansi metode istinbâth hukumnya dengan teori pengobatan dan kesehatan modern?. Jenis penelitian ini merupakan penelitian hukum normatif dengan metode penelitian kepustakaan, dalam bentuk studi tokoh. Sumber bahan primernya yakni al-Thibbal-Nabawi,didukung oleh bahan sekunder yakni al-Dâ'u wa al-Dâwa', dan bahan lainnya yang relevan. Analisis data menggunakan teknik analisis isi, materi yang terdapat dalam kandungan naskah dielaborasi dengan memahami makna yang terkandung dalam teks,lalu dilakukan interpretasi guna mendapatkan metode istinbâth hukumnya tentang metode pengobatan dan kesehatan. Hasil penelitian ini menemukan pertama,metode istinbâth hukum Ibnu Qayyim alJauziyah dalam masalah pengobatanberpedoman kepada dilâlah 'ibârah atau ibârat nash yaitu Alquran surat Yûnus [10]: 57, Al-Isra' [17]: 82, dan diperjelas oleh hadis Nabi. Sedangkan metode istinbâth hukum Ibnu Qayyim al-Jauziyah dalam masalah kesehatan merujuk kepada dilâlah 'ibârah atau ibârat nash surat al-Maidah [5]: 6, Al-'Araf [7]: 31, dan diperjelas oleh hadis Nabi. Relevansinya dengan pengobatan dan kesehatan modern, salah satunya teori tentang terapi yang terkait proses tindakan medis, yaitu dengan menjaga kesehatan tubuh melalui tindakan preventif dan melakukan proses pengusiran zat di tubuh yang menerima campuran zat berbahaya.
\end{abstract}

Kata kunci: Ibnu Qayyim al-Jauziyah; istinbâth hukum; pengobatan; kesehatan.

\section{Introduction}

Ibn Qayyim al-Jauziyah (or Ibn Qayyim) as a medieval Muslim scholar, has been known as a scholar of Fiqh and Ushul Fiqh. However, besides mastering other religious studies, he also comprehended medicine and public health. He relied his knowledge on the texts of the Quran and hadith and his research on the anatomy and the human body characteristics and features. In general, scholars divided figh studies into four types, namely worship, muamalah, munakahat, and jinayah figh. It was then developed from muamalah figh to siyasah figh and iqtishadiyah figh. In his study of medication and health, Ibn Qayyim combined the worship figh approach and muamalah figh. In terms of comprehending and interpreting the 
texts (the Quran and hadith), he employed the approach of Ushul Figh with istinbat al-ahkam to produce legal conclusions.

During his lifetime, Ibn Qayyim had made a number of essential multi-disciplinary works in the development of Islamic insight. Some of his works are: 1) Ahkam Ahli Adz-Dzimmah; 2) Miftahu Daris Sa'adah; 3) Zadul Ma'ad; 4)Madarijus Salikin; 5) I'lamul Muwaqi'in; 6) Tafsirul Mu'awwizatain; 7) Ar-Ruh; 8) Raudhatul Muhibbin; 9) Hadil Arwahi Ilâ Baladil Arafah; 10) Al-Jawabul Kafi 11) Tarikhul Hijratain; 12) 'Iddtush Shabirin; 13) Hidâyatul Hiyary; 14) Al-Fawâid; 15) Risâlah fi Amradhil Qulubi; 16) Al-Wäbil ash-Shayyib min al-Kalimi al-Thayyib; 18) Ighātsatu al-Lahfān min Mashāyidi asy-Syaithān; 19) Ighātsatu al-Lahfan fĩ Hukmi Thalāqi al-Ghadbān; dan 20) al-Thibbun Nabawi"; 21) Ad-Dâ'u wad dawâ'u; 22) Thibbul Qulub.

Various experts were amazed by the work and breadth of Ibn Qayyim's knowledge. Al-Zahabi once said: "Ibn Qayyim is very concerned about the observations of hadith and its narrator. He busied himself $a$ lot in the field of figh and had brilliant opinions. Besides that, he was also proficient in the fields of nahwu and ushũl. ${ }^{2}$. Furthermore, Ibn Kathir said: "Ibn Qayyim adhered to and practiced the correct arguments, did not ignore the opinions of others, and clung to the truth". ${ }^{3}$ The praise of the experts above affirms that Ibn Qayyim AlJauziyah was an Islamic thinker who had qualified knowledge in various fields of science. In fact, he also mastered knowledge that was not widely possessed by other scholars, namely the thought of Islamic law on medication and health. It is proven by the existence of monumental works entitled al-Thibb al-Nabawi, Al-Dâ'u wa al-Dawâ ', Thibb al-Qulub, Ighātsatu al-Lahfān min Mashāyidi al-Syaithān and Al-Jâbul Kafi". ${ }^{4}$ In general, these books were about Islamic medication and health which came from Allah and His Messenger. In summary, Ibn Qayyim said that the heart is the base of human health. When the heart is sick, it is far from Allah's commandment, it enabled various

\footnotetext{
${ }^{1}$ Ibnu Qayyim Al-Jauziyah, Al-Fawâ'id, translated by Dzul hikmah, (Jakarta: Qisthi Press, 2015), p. xviii.

2 Ibnu Qayyim Al-Jauziyah, Al-Fawâ'id..., p. 1.

3 Ibnu Qayyim Al-Jauziyah, Al-Fawâ'id..., p. 1.

4 Ibnu Qayyim Al-Jauziyyah, Al-Thibb al-Nabawi, (Beirut: Dar al-Kutub al ilmiyyah, 2002M/1423H), p. 32.
}

types of diseases to affect the body as the place for the heart. On the other hand, a healthy heart will reject disease or be able to defeat it. ${ }^{5}$

In more detail, the contents of the book alThibb al-Nabawi are categorized into three major themes, namely: first, an explanation of natural medication and health based on biological and animal wealth. For example, treatment using water, honey, and milk media is described in $\mathbf{3 5}$ articles. Second, the explanation of the law of treatment and healing using spiritual power relies on advice and wisdom. Advice taken from the Quran and Sunna of the Prophet Muhammad, this treatment is intended for types of diseases that originate from the human heart and mind (al-qalb wa al-fua'd) which are described in 23 articles. Third, the explanation about the laws regarding medicines and food mentioned by Prophet Muhammad, intended to treat diseases and maintain health, is described in 132 Articles. $^{6}$

Based on his work, Ibn Qayyim al-Jauziyah's method of legal intinbâth is particularly interesting to be reviewed in terms of his understandings of medical and health problem extracted directly from the Quran and hadith. Regarding the legal study of preventive medical and health, Ibnu Qayyim al-Jauziyah explained:

"Treatment is first, maintaining health; second, eliminating disease; third, rejecting and avoiding disease. There are three methods: 1) maintaining health, 2) guarding from heat that brings disease, 3 ) releasing things that bring destruction. These three things are the isyarah from the Quran."”

\section{Method}

This is normative legal research with a library research method, in the form of a character study. The source of the primary material is al-Thibb alNabawi, supported by secondary materials, al-Dâ'u wa al-Dâwa', and other relevant materials. The data analysis used content analysis techniques, by elaborating the material contained in the text

\footnotetext{
${ }^{5}$ Ibnu Qayyim Al-Jauziyyah, Manhaj Tarbiyah Ibnu Qayyim, translated by Muzaidi Hasbullah, (Jakarta: Al Kautsar, 2001), p. 21.

${ }^{6}$ Ibnu Qayyim Al-Jauziyah, Al-Thibb al-Nabawi..., p. 5.

7 Ibnu Qayyim Al-Jauziyah, Al-Thibb al-Nabawi..., p. 6.
} 
through understanding the deep meaning within it, then interpreting the matters in order to obtain Ibn Qayyim al-Jauziyah's legal istinbâth method on medication and health, and its relevance to medicine and health in the modern.

In understanding and interpreting literature and text, the author employed the hermeneutic method, by interpreting the text based on the context of the content in the text. This is intended as an effort to understand the meaning of the text (holy books, books and others), which serves to avoid distortion of messages or information between the text writer and the text reader.

\section{The Profile of Ibnu Qayyim al-Jauziyah}

Ibnu Qayyim al-Jauziyah had two nicknames, Abu Abdillah, Syamsuddin Muhammad bin Abi Bakr bin Ayyub ibn Sa'ad bin Huraiz bin Makiy Zainuddin az-Zar'i al-Dimasyqal-Hambali. He was also known as Syamsuddin. ${ }^{8}$ He was born in Damaskus on 7 Safar $691 \mathrm{H}$ or 04 February 1292 A.D. The title alJauziyyah was pinned by local residents because his father served as the head of the al-Jauziyah Madrasah in Damascus. Previously, the school was built by a scholar named Muhyiddin ibnu al'Alamah al-Hafizh Abdurrahman al-Jauziyah. His son automatically also got his father's name as Ibn al-Qayyim al-Jauziyah (son of the person in charge of the madrasa al-Jauziyah). ${ }^{9}$

Ibn Qayyim studied under his father's care and guidance. At the age of about seven years, he had studied hadith and other sciences in the majlis of his shaykhs/teachers. At this age level he had studied several juz related to Ta'bir al-Ru'yâ (dream interpretation). From Shaykh Syihabuddin al-'Abir, he also mastered the knowledge of nahwu and other Arabic sciences in his shaykh Abu al-Fath al-Ba'labakki, such as Alfiyah Ibn Malik and others. ${ }^{10}$

Furthermore, Ibn Qayyim studied hadith from Syihab an-Nablusi and Qadhi Taqiyyuddin bin Sulaiman. He studied figh from Sheikh Safiyyuddin

8 Ibnul Qayyim Al-Jauziyah, Al-Taubah Wa al-Inabah, translated by Ahmad Dzulfikar, (Jakarta: Qisthi Press, 2012 ), p. 13-14. See Ibnu Qayyim Al-Jauziyah, Ighatsatul Lahfan min Mashayidis Syaithan, translated by Hawin Murtadha \& Salafuddin Abu Sayyid, (Jakarta: Al-Qawam, 2017), p. viii.

9 Ibnul Qayyim Al-Jauziyah, Al-Taubah Wa al-Inabah..., p.14.

${ }^{10}$ Ibnu Qayyim Al-Jauziyyah, At-Taubah Wa al-Inabah..., p. 17
al-Hindi and Ismail bin Muhammad al-Harrani, and learned the knowledge of inheritance distribution from his father. In addition, he also studied for 16 years from Ibn Taymiyyah. He absorbed all the knowledge of the teacher by means of dialogue and discussion. Therefore, Ibn Qayyim inherited Ibn Taymiyyah's figh science and methodology, so that he could freely issue fatwas. If Ibn Taymiyyah in his life focused more on the issues of fiqh, fatwas and faith, then Ibn Qayyim only adopted fiqh and the methodology. ${ }^{11}$ He used all his time to study and deepen the main points of Islamic teachings as well as fighting atheism, falsehood, and corruption. Most of his life was spent fighting the problems of innovation and khurafat that developed. He upheld the faith of the salaf, followed in the footsteps of Ibn Taymiyyah and freed the principles of Islamic teachings that had blended with bid'ah and khurafat. ${ }^{22}$

Ibn Qayyim's writings were the result of deep thought, strong reflection, well organized, consecutive chapters, brilliant thoughts, and clear explanations. His writings are a collection of the depth of thinking and the breadth of reach and written in a good word order, without waste of words and complicated explanations. ${ }^{13}$

Studying from the great scholars who were known to be knowledgeable and noble, Ibn Qayyim not only took their knowledge, but also delved into their thoughts and were influenced by them. Indeed, Ibn Qayyim's teachers were numerous. However, the person who had the greatest services in educating Ibn Qayyim and the greatest position in his heart and closest to him was Taqiyyuddin Ahmad Ibn Taymiyyah. Two of his works, I'lam al-Muwaqqi'in and Zad al-Ma'ad as well as several other books, are the fruits of the legacy of Ibn Taymiyyah. ${ }^{14}$ As a close friend who both studied with Ibn Taymiyyah, Ibn Kathir, in his book Al-Bidayah Wa al-Nihayah conveyed his appreciation of this teacher and student:

"When Shaykh Ibn Taymiyya returned from Egypt in 712 A.D., Ibn Qayyim al- accompanied

"Ibnu Qayyim Al-Jauziyah, al-Fawa'id, translated by Dzul Hikmah, (Jakarta: Qisthi Press, 2015).p.2.

${ }_{12}$ Ibnu Qayyim Al-Jauziyah, al-Fawa'id, translated by Munirul Abidin, (Jakarta: Pustaka al-Kautsar. 2009, p. XV.

${ }^{13}$ Ibnu Qayyim Al-Jauziyah, al-Fawa'id..., p.XVii

${ }^{14}$ Ibnu Qayyim Al-Jauziyah, al-Fawa'id..., 15. 
him until he died and received a lot of knowledge from him. Besides that, he also worked on his various needs. So, he became a very rare person to find a match. However, he also had time to increase his prayers day and night with various requests." 15

Ibn Qayyim mastered many various kinds sciences. Expert in understanding the The Quran and Sunna, ushuluddin, Arabic, kalam knowledge, morals, and other disciplines. He gave many benefits to people who lived during his time, even many scholars who solemnly studied him. Until now, his works are still a source of light and well-known ${ }^{16}$.

Ibn Qayyim was very persistent in fighting blind imitation and calling for the truth of thinking, by sticking to the principles of Islamic teachings and the creed of the salaf. He also had an open mind and broad insight as well as mastered various kinds of knowledge, especially the science of interpretation, fiqh and Sufism. ${ }^{17}$ Ibn Qayyim did not limit himself to any particular school. Before expressing his own opinion regarding a problem, he first attempted to find out the opinions of the different groups regarding the problem, then examined it carefully with in-depth analysis. In this way, he eliminated falsehood and upholded the truth that he noticed as a truth. ${ }^{18}$

From here the school of Ibn Qayyim stood, which is based on the principle of ittiba'. His school was not influenced by any emotional attachment or sect, but was built purely on the principle of truth. This concept went hand in hand with his efforts to fight blind imitation, as well as his persistence in defending his ideas and opinions based on the Quran and Sunna, as well as in order to straighten the takwil following the lusts that developed at that time. From here, Ibn Qayyim's manhaj aqidah is in line with the Salaf creed in terms of leaving takwil and understanding zahir texts as they are. The meaning is returned to Allah Swt. ${ }^{19}$

\footnotetext{
${ }^{15}$ Ibnu Qayyim Al-Jauziyah, al-Fawa'id..., 15.

${ }^{16}$ Ibnu Qayyim Al-Jauziyyah, Fawaidul Fawaid, (Jakarta: Pustaka Imam Asy-Syafi'i, 2016).

${ }_{17}$ Ibnu Qayyim Al-Jauziyyah, Terapi Mensucikan Jiwa, (Jakarta: Qisthi Press, 2015).

${ }^{18}$ Ibnu Qayyim Al-Jauziyyah, Fawaidul Fawa'id..., p. 11.

19 Ibnu Qayyim Al-Jauziyyah, Fawaidul Fawaid..., p. 11.
}

Ibn Qayyim's main target was to save the Muslims of his time from various internal strife and differences of opinion among themselves. Especially on matters that are not worthy of dispute by those who defend the religion of Allah. He considered these disputes would only worsen conditions and neglect the Muslims from the enemies who were fighting in the middle ages. ${ }^{20}$

The sources that became the reference for Imam Ibn Qayyim al-Jauziyyah in finding the law were the Quran and Sunna, and ijma', provided it is known that there is no other opinion that resolves it. The next reference is the fatwa of the Tabi'in (generation after the khulafaurasyiddin), then the fatwa of the Tabi'ut Tabi'in (the generation after the Tabi'in), and so on. After all that has been passed, then he moved to qiyas (analogy with existing laws), istshhab (adhering to the previous law), mashlahah (maslahat and mudharat review), saddudz dzari'ah (preventive action), and 'uruf (custom). ${ }^{21}$

Ibn Qayyim was imprisoned for the first time with Ibn Taimiyyah at Damascus Fortress. During their period of detention, they were placed in separate cells. He was only released after Ibn Taimiyyah passed away. He was imprisoned again for defending Ibn Taimiyyah's Fatwa. He also once opposed Syadd al-rihal (recommended to travel) to visit the tomb of the Prophet Muhammad, and because of this opposition he had to reside in the prison for the third time. ${ }^{22}$ During his imprisonment, he was busy reading the Quran and contemplating on its verses. From this practice, a lot of goodness would emanate. From here also, the dzauq (pleasure in understanding something) and mawajid (love in doing business) that he really got. Therefore, it is not surprising if he mastered the discussions that Sufis and makrifat experts had and was able to understand and comprehend the meaning of their words and isyarah.

Ibn Qayyim al-Jauziyyah's writings are the product of deep thought and intensive reflection.

\footnotetext{
${ }^{20}$ Ibnu Qayyim Al-Jauziyyah, Fawaidul Fawaid..., p. 12

${ }^{21}$ Ibnu Qayyim Al-Jauziyyah, Fawaidul Fawaid..., p. 13

22 To find out more about the trials and tests experienced by Ibnul Qayyim Al-Jauziyyah and Ibn Taimiyyah, see: Ibnu Taimiyyah, Mahbbatullah Baina al-'Abdu Wa ar-Rabb tahqiq:Abdullah Badran and Abdurrahim Barmu. p.16.
} 
The writing is particularly neat, orderly, smart, and clear as well as effective. His works are a combination of depth of thinking with facts. ${ }^{23}$ These works are a summary of the knowledge obtained from his teacher, in addition to the results of his own studies that showed his tendency. ${ }^{24}$ The works combined the weight and depth of ideas, between the beauty of the editorial of sentences and consistency of composition, without having to waste words. Ibn Qayyim was inspired a lot from previous generations of salaf and wisdom experts. He often made the words of friends and tabi'in as his basis, even though they were not his teachers. The number of written works reached $120 .{ }^{25}$

\section{Ibn Qayyim Al-Jauziyah's Legal Istinbâth in the Field of Medication and Health 1. Legal Istinbâth in the Medication Sector}

According to Ibn Qayyim, the Quran is a perfect, effective medicine, which can heal all physical and psychological ailments. He also stated that the Quran is Syifâ'un limâ fi al-shudûr, which is a cure for mental illnesses, an antidote for all kinds of diseases. Due to seeing the dilâlah, this includes dilâlah ibârah, or also called ibâratun nash. The legal basis used here is first, ${ }^{26}$ Allah stated in Yûnus [10] verse 57:

"O mankind! There hath come unto you an exhortation from your Lord, a balm for that which is in the breasts, a guidance and a mercy for believers."

Wahbah Zuhaili explained about Yûnus [10] verse 57 above which is "O people (in Mecca and others), have come to you a deep and memorable lesson, namely the Al-Quran which contains commands to obey the truth and do good and stay away from evil and the badness (in the form of a sentence containing targhib (motivation) and tarhib (threat). In addition, it is also a panacea for diseases that strike in the chest (broken faith and doubt), leading to things that bring to heaven,

${ }^{23}$ Ibnu Qayyim Al-Jauziyyah, Terapi Mensucikan Jiwa..., p. 3

${ }^{24}$ Ibnu Qayyim Al-Jauziyyah, Tobat dan Inabah..., p. 20

${ }^{25}$ Ibnul Qayyim Al-Jauziyyah,al-Tawbah wa al-Inabah...,p. 20-21; see Ibnu Qayyim Al-Jauziyyah, Ighatsatul Lahfan..., p. xviii-xx

${ }^{26}$ Ibnu Qayyim al-Jauziyah, I'lamul Muwaqi'in, Panduan Hukum Islam, translated by Asep Saefullah et.al. (Jakarta: Pustaka Azzam, 2010), p. 454. as a gift from Allah who produces goodness and gentleness for believers. The content of the Quran has people to receive mercy, encourages to always obey Allah and Rasul, reminds us of the torments of the hereafter, and motivates to get eternal enjoyment in heaven. ${ }^{27}$

In understanding the explanation of the interpretation of the above verse, it can be understood that this verse begins with the sentence "Yâ Munada" (call to command) by using the editorial news that is profound and memorable, namely the command to truth and do good, stay away from evil in the form of sentences containing targhib (motivation) and tarhib (threats). In addition, there is another at the end of the verse the word "wa rahmatun li al-Mukminin". This verse in the study of Ushûl Fiqh contains maqâshid al-syari'ah, namely the purpose of Allah and His Messenger in formulating and stipulating laws in Islam. This goal can be traced in the verses of the Quran and the Sunna of the Prophet as a logical reason for the formulation of a law oriented towards the benefit of mankind. ${ }^{28}$

The second dilâlah, is dilâlah ibârah or also known as ibâratun nash, as Allah stated in Al-Isra '[17]: verse 82:

"And We reveal of the Qur'an that which is a healing and a mercy for believers though it increase the evil-doers in naught save ruin."

In his work al-Thibb al-Nabawi, Ibn Qayyim concluded that the Quran is a syifa'un (healer) in the chest, namely the soul. Ibn Qayyim took the verse because he saw that it contained dilâlah ibârah or 'ibâratun nash. That is the basis of Ibn Qayyim's methods in his istinbâth. When Allah Himself revealed through the Quran, the conclusion of the verse stated in the text is ibâratun nash as the highest guidance, the text immediately mentions that, nothing more and nothing less.

Regarding the human soul mentioned above, the explanation given by Ibn Qayyim is the treatment of shudũr (soul), if Allah declares fial-

${ }^{27}$ Wahbah Zuhaili dkk., al-Mausû'ah al-Qur'aniyyah alMuyassarah, translated by Imam Ghazali Masykur et.al. (Jakarta: Penerbit Almahira 2008), p. 216

${ }^{28}$ Satria Effendi, Ushul Figh, (Jakarta : Kencana, 2008), p. 233. 
shudũr, this is because physical and shudr cannot be separated. Although Allah states only shudũr, due to its relevance, it can be developed, called dilâlah ibârah. Therefore in al-Thibb al-Nabawi, Ibn Qayyim wrote verses or hadiths relating to medicine, because Ibn Qayyim was a commentator scholar. Ibn Qayyim is not a doctor, but because of his ability to understand and process verses, this verse comes the law of istbat al-syai'i 'ala alsyai'i - stipulating something on something/not obligatory or sunnah or sharia law). He stipulated the argument for producing madlul, the argument for the Quran and its madlul is medication and health. ${ }^{29}$

By paying attention to this verse, Ibn Qayyim said, "Do we have to seek treatment (to a doctor) if we get a disease? He explained it with several traditions, among them:

"From Ziyad bin Ilaqah from Usamah bin Sharik he said; the Baduwi Arabs said, "O Messenger of Allah, don't we have to seek treatment (if we are sick)?" He replied: "Yes, O servants of Allah, seek treatment in fact Allah does not create a disease but also creates a medicine for it except for one disease." They asked, "What disease is that, O Messenger of Allah?" He replied: "Namely old disease (senile)." Abu Isa said; The hadith is narrated from Ibn Mas'ud, Abu Hurairah, Abu Khuzamah from his father and Ibn Abbas. And this is a hasan sahih hadith." (Narrated by Tirmidzi). ${ }^{30}$

In another narration, the Prophet said about the best medicine:

"From 'Uthman bin Abu Al' Ash al-Tsaqafi that he complained to the Messenger of Allah, a disease he had suffered since he converted to Islam. So the Messenger of Allah said to him: "Put your hand on your body that feels sick, then say Bismillah three times, after that read it seven times: A'udzu billahi wa qudratihi min syarri ma ajidu wa uhadziru." (I took refuge in Allah and His power from the disease that I suffered and I worried about)". (Narrated by Bukhari) ${ }^{31}$

Paying attention to the verses of the Quran and the hadith, Ibn Qayyim understood that in

\footnotetext{
${ }^{29}$ Amir Syarifuddin, interview, Padang, September 15, 2019.

30 Ibnu Qayyim Al-Jauziyah, I'lâmul Muwaqqi'in..., p. 394

${ }^{31}$ Ibnu Qayyim Al-Jauziyah, Ilâmul Muwaqqi’in..., p. 395
}

comprehending the law of medication and health, it is to use the method of dilâlah 'ibârah or ibâratun Nash. Dilâlah 'ibârah is a meaning that can be understood from what is mentioned in lafazh, either in the form of text or zahir..$^{32}$ In this case, it can be understood that lafadzh is closely related to the intent, intention and desire of the speaker, namely in accordance with what is meant by lafazh. This conformity is obtained from the existence of confidence and certainty about the speaker's intent with the utterance. The meaning that can be understood is the meaning of the expression which includes the wishes of the speaker and the desires of others (listeners), where one another is not stronger, 33 protect and grant it only Allah Swt.

After observing the lafadz texts of the Quran and the above hadiths, it can be understood that the legal meaning of medication and health is contained in the principle of Ushûliyah "al-Amr Yufid al-Wujub" (Command shows mandatory). That is, every fi'il amr shows an obligation. Likewise the principle of "La Masagha li al-litihad fi Maurid alNash" (It is not justified to do ijtihâd in problems with texts). Therefore, if a text has been believed to have its source (the Quran and hadith) and the meaning and purpose of which it is intended is clear (qath $i$ ), then there is no longer any chance of doing ijtihad on it. ${ }^{34}$ In another ushûliyah rule it reads: "al-Amr bi al-Syai'i Nahyun' an Dhiddihi "(An order against something means prohibition of its opposite) $)^{35}$. The point is that the command to seek treatment means the prohibition of not wanting to seek treatment, as well as the command to pray means the prohibition to leave prayer.

The third Dilâlah ${ }^{36}$ is'ibârat nash, Allah stated in Al-Fushshilat [41] verse 44:

"Say unto them (O Muhammad): For those who believe it is a guidance and a healing; and as for those who disbelieve, there is a deafness in their ears, and it is blindness for them. Such are called to from afar.."

\footnotetext{
32 Amir Syarifuddin, Ushul Figh 2, (Jakarta: PT.Logos Wacana Ilmu, 2001), p. 148.

33 Amir Syarifuddin, Interview, Padang, September 15, 2019.

34 Toha Andiko, Figh Kontemporer, (Bogor: IPB Press, 2014), $1^{\text {st }}$ edition, p. 54.

35 Hasbiyallah, Fiqh dan Ushul Fiqh, Metode istinbâth dan Istidlal, (Bandung: PT. Remaja Rosdakarya, 2013), p. 131.

${ }^{36}$ Ibnu Qaiyyim Al-Jauziyah, Al-Dâ'u wa al- Dawâ'u, (Mesir: Dâr Ibnu Al-Jauziy, 1433 H/2012 M), p. 8.
} 
What a darkness means to them is not to guide them. For this reason, it is necessary to analyze and to look for evidence, what is the substance of the Quran as a healing for body and soul. The verses of the Quran, although the process of understanding is carried out through translation, cannot be directly understood by respondents. ${ }^{37}$ As Prophet Muhammad PBUH stated:

"From Abu Salih from Abu Hurairah from the Prophet, he said: "It is not a people who gather in the house of the houses of Allah 'azza wajalla, read and study the book of Allah, and study it together, unless the angels will surround them. They will filled with mercy, and Allah will mention them in front of the angels who are by His side. And there is not a man who walks the path in order to study, except Allah will make it easier for him the way to heaven, and someone who is slowed down by his deeds, cannot be accelerated by the lineage." 38

Similar research conducted by Ramis Thaha, a mental medication expert from al-Azhar University, shows that the treatment carried out by reading the Quran and listening to the recitation of the Quranic verses has a profound impact on the healing process for sufferers of mental disorders. The treatment success rate reached $80 \%$. Likewise, according to Said Abdul Azhim from Cairo University who said that treatment with the Quran, apart from chemical drugs, would be much more effective if the person undergoing it had strong faith and belief in Allah Swt as well as the truth of the Quran as His words.

The forth Dilâlah'39 is dilâlah 'ibârah or'ibâratun nash, Allah SWT stated in al-Nahl [16] verse 66:

"And lo! in the cattle there is a lesson for you. We give you to drink of that which is in their bellies, from betwixt the refuse and the blood, pure milk palatable to the drinkers."

Ibn Qayyim further explained about the verse, "milk can concretely improve body ions after intercourse, it is very suitable for people

37 Jamal Elzaky, Buku Induk Mukjizat Kesehatan Ibadah, (Jakarta: Penerbit Zaman, 2011), p. 418.

${ }^{38}$ Narrated. Ahmad (Lidwa Pusaka i-SoftwareKitab 9 Imam Hadis, Hadis No. 8906).

39 Ibnu Qayyim al-Jauziyah, Al-Thibb al-Nabawi, (Mesir: Darul- Hadits, 1429 H), p. 262. see hadits No, 5179. with chest and lung disease, both stomach, liver and spleen. If you drink too much, it can damage your teeth and gums. Therefore, after drinking milk, you should rinse your mouth with water. In Sahih al-Bukhari it is stated that the Prophet Muhammad used to drink milk, then asked for water to rinse his mouth, he said, "Milk contains fat." (H.R. Bukhari) ${ }^{40}$

Based on Ibn Qayyim's previous explanation who wrote the law directly from the text, this is clearly using the ijtihad method. Ibn Qayyim's method of ijtihad is to use dilâlah 'ibârah or called ibâratun nash. Ibn Qayyim used 'ibâratun nash in his book al-Thibb al-Nabawi by directly mentioning medicine in the Quran. He explained the verse based on direct information in the Quranic verse itself which relates to medicine. From this, Ibn Qayyim drew conclusions ibâratun nash (the highest level in istinbâth).

One of the ways in doing ijtihâd is istinbâth. ${ }^{41}$ So istinbâth is a form of ijtihâd work. This ijtihâd effort is pursued through istinbâth methods ${ }^{42}$ guided by istiqra, (empirical research) which is based on dilâlah'ibârah or also known as ibârat nash" 43 The istinbâth is direct from the text. If not from the text, it is not called istinbâth but istidlal. ${ }^{44}$

Discussing about medical problems, the Quran contains the cure for all diseases. The root of all the biggest and most severe liver diseases is syubhat disease and lust. 45 The Quran is a remedy for both liver diseases. The word oِ from surah al-Isra '[17]: 82 above serves to explain the type, or in the study of ushûl figh it is called one of the methods of ijtihâd, not to determine a part. Because the entire the Quran is a healer, an antidote, as Allah has enshrined in His word in the above verse. The Quran is a healer for the heart from ignorance, doubt, and indecision. ${ }^{46}$

\footnotetext{
40 Ibnu Qayyim al-Jauziyah, Al-Thibb al-Nabawi, p. 263.

${ }^{41}$ Amir Syarifuddin, Interview, Padang, 15 September 2019. See the book Ushul Figh 2, p.148.

${ }^{42}$ Amir Syarifuddin, Ushul Figh 2..., p. 226.

${ }^{43}$ see Muhammad Abu Zahrah, Ushũl Fiqh, (Beirut: Dar al-Fikri al-'Arabby, t.th,), p. 277.

${ }^{44}$ Amir Syarifuddin, Interview, Padang, September 15, 2019.

45 Ibnu Qayyim Al-Jauziyah, Ighatsatul Lahfan min Mashâidisy Syaithan, translated by Hawin Murtadho, (Solo: AlQawam, 2011), p. 69.

${ }^{46}$ Ibnu Qayyim al-Jauziyyah, Al-Dâ'u wa ad-Dawâ'..., p. 8. see Terapi Syar'i Mengobati Penyakit Hati, resumed by Ahmad
} 
The meaning of the word syifa 'in this context is the healer of the heart from negligence, ignorance, doubt, anxiety, and prejudice. Allah does not send a healer who is more effective at treating diseases than other than the Quran. ${ }^{47}$ In Sahih Bukhari and Muslim, from Sanad Abu Sa'id narrated:48

"From Abu Sa'id r.a. said, there was a group of several people from the companions of the Prophet. who traveled on a trip until when they arrived at an Arab village of the local population, they asked to accept them as guests, but the residents refused. Then the chief of the village tribe was stung by an animal, so everything was tried to cure him, but nothing was successful. Then some of them said: "Try to find that group, hopefully some of them have something. Then they came to the group and said:" O ye, actually our chief has been bitten by an animal and we have tried the treatment but it has not been successful, Is there any of you who can heal him? "At that time said, a man from the group:" Yes, by Allah I will heal but by Allah yesterday we asked to be your guest, but you are not pleased, so I will not be the one who medicate unless you pay. Finally they agreed in exchange for dozens of goats. So he went and read Alhamdulillahi rabbil 'alamin (Q.S Al-Fatihah) as if the disease were free from the rope, even though he left without any medicine. He said: "So they paid the wages they had agreed to him. One of them said:" Divide the goats! "So the medic said:" Do not share until we meet Prophet Muhammad, then we tell the incident to him. and we are waiting for what he will order to us ". Finally the group went to the Prophet and they told him the incident. He said:" How do you know if Al-Fatihah can be a ruqyah (medicine)? "Then he continued:" You have done right deeds, so divide the wages of the goats and put me in the portion of the person who receives the reward. Then Rasulullah PBUH laughed". (Narrated by Bukhari and Muslim) ${ }^{49}$

Bin Utsman Al-Mazyad, translated by Izzudin Karimi, (Jakarta: Darul Haq, 1437 H), p. 3.

${ }^{47}$ Ibnu Qayyim Al-Jauziyyah, Ad-Dâ'u wa ad-Dawâ' (Terapi Penyakit Hati) translated by Salim Bazemol, (Jakarta : Qisthi Press, 2017), p. 3.

${ }^{48}$ Ibnu Qayyim Al-Jauziyyah, Ad-Dâ'u wa ad-Dawâ'..., p. 3. see Aplikasi Hadis Sembilan. No. 2115.

49 Ibnu Qayyim Al-Jauziyyah, Ad-Dâ'u wa ad-Dawâ'..., p. 8.
The conclusion of the above verses of the Quran and hadith, it turns out that reading the Quran is able to completely heal and overcome illness, as if nothing had happened. Al-Fatihah is the easiest and most effective medicine. If it is used for treatment properly, someone will certainly see amazing results.

A companion of the Prophet once said, "I stayed in the city of Mecca for some time. Suffered from various diseases and did not see a doctor or medicine. So I tried to treat myself with surah al-Fatihah. I was cured. Because of that, I say that whenever someone complains of being sick. After practicing it, most of them recovered quickly." ${ }_{50}$ In interpreting this, Ibn Qayyim used dilâlah 'ibârah or 'ibâratun nash, because in the hadith of the Prophet it was directly mentioned such things.

Ibn Qayyim was not a doctor, but from understanding the verse, he was able to cultivate it. From the ability to cultivate at most only a little experience that is used by Ibn Qayyim. People thought that Ibn Qayyim is talking about medication and health. When it came to regulations, do not consider this law obligatory, this is sunnah. Law is not only a matter of obligation, it is sunnah, because law is to determine something over something. Here, in his position he raised the law, not in the sense of syar'i law. He determined something, namely the argument for producing madlul, the argument for the Quran and its madlul is medication and health. Medication and health are generated from arguments, it took the ability to cultivate these arguments when they appeared to be madlul talking about medication and health. This is what was discussed a lot in al-Thibb alNabawi, researched, studied, and processed by Ibn Qayyim so as to produce the madlul pointed to by the above argument, with nuances of medication and health. Not necessarily a doctor, but he can understand that these are medical texts. ${ }^{51}$

In another hadith, Ibn Qayyim used the guidance of the Prophet in carrying out natural fever therapy. It is narrated in the book Sahih alBukhari and Muslim, from the Nafi 'of Ibn Umar that the Prophet had said:

\footnotetext{
${ }^{50}$ Ibnu Qayyim Al-Jauziyyah, Terapi Penyakit Hati..., p. 4.

${ }^{51}$ Amir Syarifuddin, Interview, Padang, September 15, 2019.
} 
"From Ibn Umar radliallahu 'anhuma from the Prophet, he said: "Fever comes from the blowing of hell, so reduce it with water." ${ }_{52}$

All forms of fever when body heat increases sharply can be treated using water, in two ways: First: from the outside, namely by compressing it using cold water or ice with the aim of reducing the degree of heat. Second; Sipping water through the mouth as much as possible when you have a fever, it can help all organs, especially the two kidneys, to return to normal doing all body activities. The above hadith was narrated by An-Nasa'i, Ibn Majah, Malik and Ahmad. ${ }^{53}$

Prophet Muhammad once said "...The fever comes from the steam of hell, that is, the fever is churning". As the Prophet once stated, "The scorching heat of the sun comes from the steam of hell". Regard to the above hadith, there are two interpretations: first, the heat is an example and a small part is taken from jahannam, so that the servants of Allah make it an indication of hell and make it a lesson. Then Allah predestined the existence of the hellish steam with various causes. As the soul, joy, and pleasure are part of the pleasures of heaven, which Allah shows in the life of this world, as lessons and indicators of the existence of heaven itself. Allah predestined the existence of heaven with various causes and consequences. Second, what is meant in the hadith is tamtsil. Allah likens the heat of a fever that rises like the steam of hell. Allah also likened the sun to the steam of Jahannam. As a warning to humans about the heat of hell's torments. That the scorching heat is likened to the steam of hellfire, people who approach it will be touched by the heat. ${ }^{54}$

Furthermore, Ibn Qayyim explained that based on the hadith in Ibn Majah's sunan, there is a history of marfu' from Abu Hurairah:

"From Abu Hurairah he said, "Rasulullah SAW. Said:" Whoever drinks honey three mornings (three times) in each month, then he will not

${ }^{52}$ Ibnu Qayyim Al-Jauziyah, Al-Thibbun Nabawi..., p. $23-24$. see hadits No.5282.

53 Ibnu Qayyim Al-Jauziyah, Al-Thibbun Nabawi..., p. 24

54 Ibnu Qayyim Al-Jauziyah, Al-Thibbun Nabawi, Metode Pengotan Nabi, Pentahqiq: Abdul Ghani Khaliq. Penta'liq: Adil Al-Azhari. Pentakhrij: Mahmud Farraj Al-Uqdah, (Jakarta: Griya Ilmu,1435 H/2014 M), p. 36. suffer heavy bala' (disease)."(Narrated by Ibnu Majah) $)^{55}$

Other above mentioned:

"From Abdullah he said, "The Rasulallah said:" Use two kinds of healing therapy; honey and the Al-Quran."(Narrated by Ibnu Majah)" "56

Observing this hadith, there is a combination of human medicine with divine guidance, between physical and spiritual therapy, between earth elemental medicine (biological wealth) and medicinal elements from heaven, namely Allah's guidance. The lesson that can be taken from the information above is that all kinds of dhikr, verses of the Quran, and medicine are useful for healing. Including the fulfillment of prayers is very much determined by the strength and willpower of the person concerned. The arrival of healing is greatly influenced by the perpetrator. A prayer is not answered, sometimes the result of a strong barrier blocking the efficacy of the drug. ${ }^{57}$ It is in the nature of medicine that if the substance is not strong enough, it will fail to cure the disease. So if you want a drug to function perfectly, a person must meet the conditions for using the drug. ${ }^{8}$ Likewise the heart, if you use prayer as medicine with the belief that the prayer will be answered, the user must have a very sincere and clean soul, because this will have a major effect in the effort to cure a disease. ${ }^{59}$

Prayers are not answered due to obstacles, for instance unlawful food, sins, and things that are prohibited by Allah. Ibn Qayyim Al-Jauziyah told a story from the Prophet about a person who was on a long journey so that his hair was matted and gray. This person raised his hand to the sky while praying, "O Allah, O Allah ..." while his food was haram, his clothes were haram and his body contained haram food substances. So how could someone like that his prayer will be granted. ${ }^{60}$ This can only be read in alThibbun Nabawi. Is he just giving an explanation or producing a conclusion. Paying attention to the verses of the Quran and the hadith of the

\footnotetext{
55 Ibnu Qayyim Al-Jauziyah, Al-Thibbun Nabawi..., p. 30.

${ }^{56}$ Ibnu Qayyim Al-Jauziyah, Al-Thibbun Nabawi..., p. 31.

57 Ibnu Qayyim Al-Jauziyah, Al-Thibbun Nabawi..., p. 35.

${ }^{8} 8$ Ibnu Qayyim Al-Jauziyyah, Ad-Dâ'u wa ad-Dawâ'..., p. 9.

59 Ibnu Qayyim Al-Jauziyyah, Ad-Dâ'u wa ad-Dawâ'..., p. 5.

${ }^{60}$ Ibnu Qayyim Al-Jauziyyah, Terapi Penyakit Hati..., p. 6.
} 
Prophet. Which method of ijtihâd was suitable for Ibn Qayyim Al-jauziyah? When viewed as a whole, there are many who are dilâlah 'ibârah or also called ibâratun nash, on that basis Ibn Qayyim interrogated the law so it can be understood that “Ibn Qayyim Al-Jauziyah's ljtihâd Method in the problem of healing is to use the dilâlah ibâd method, because one of the methods of doing ijtihâd is through istinbâth methods. Istinbâth is a form of ijtihâd work based on istiqra' (empirical research) from dilallah' ibârah or also called 'ibâratun nash. ${ }^{61}$

\section{Legal Istinbâth in the Sector of Health}

According to Ibnu Qayyim Al-Jauziyah ${ }^{62}$, the guidance of the Prophet Muhammad PBUH, in maintaining health, it is clear in the Quran, for example, eat and drink, but don't overdo it. This is the method of legal istinbâth on health which is based on dilâlah 'ibârah or also called 'ibâratun nash, ${ }^{63}$ Allah stated in Al-A'raf [7] verse 31:

"Eat and drink, and don't overdo it. Surely Allah does not like people who are extravagant".

It means, "do not exceed the limits needed by the body and do not go beyond the limits of halal food". Because in the view of the Quran, eating is a means, not an end. It is an important means for maintaining health, for the continuation of human life. Ibn Qayyim here is guided by the Quran and the Prophet's instructions in maintaining health. The ijtihâd method used by Ibn Qayyim in maintaining health is called the ibâratun nash method which is written directly in the Quran, although it does not address the medicaction and health. Therefore, this verse shows and becomes madlul health, it is called 'ibâratun nash. ${ }^{64}$

The stability of the body, health, and fitness can only be achieved through the element of moisture which can match heat. The moisturizing element is the basic material. Meanwhile, the hot temperature functions to ripen the material and expels the waste of useless metabolism, then repairs and stabilizes it. If it doesn't work, it will

\footnotetext{
${ }^{61}$ Amir Syarifuddin, Ushul Fiqh 2..., p. 136.

62 Ibnu Qayyim Al-Jauziyah, Al-Thibbun Nabawi..., p. 146.

${ }^{63}$ Amir Syarifuddin, Ushul Figh 2..., p. 137.

${ }^{64}$ Amir Syarifuddin, Ushul Figh 2..., p. 136.
}

damage the body, so that the body cannot stand upright. ${ }^{65}$

Likewise with humidity which is food for these hot temperatures. If there is no moisture, the body must be burnt, dry, and damaged. The two elements must complement each other, because the body can only stand upright with these two elements. Each of them becomes useful material for the others. Heat becomes the basic material for humid temperatures, becomes and preserves it so that it is not easily damaged and contaminated. ${ }^{66}$

In addition, moisture is the basic material for heat, injects nutrition, and provides resistance. If one of the two elements dominates a person's body excessively, there will inevitably be an irregularity in the body's metabolic system according to the excess level of that element. Hot temperatures will forever dominate the cold element, so that the body will need a replacement for the substances that are lost after the body undergoes a burning process to stay fit, namely through food and drink. If the cold temperature exceeds the ability, heat energy burns useless body substances so that they become contaminated into dangerous rotten materials, and eventually damage and fragile a person's body and cause various diseases, according to the type of material produced by the contamination. It also depends on the body's resistance to it. All of these are lessons that can be learned from the word of Allah in Al-Baqarah [2] verse 168:

"O people, eat what is clean and good that is on the earth, and do not follow Satan's steps."

In this verse, there is an appeal to humans to eat and to drink. However, after that there was a direct warning not to overdo it in it. Simple attitudes of eating and drinking were practiced in the life of the Prophet and his companions. Lukman al-Hakim once gave a message to his son. "If you are eating, take care of your stomach". Umar bin Khatthab also warned about greediness in eating and drinking. He said, "avoid being greedy in eating, because actually it can cause damage to the body and cause disease". ${ }^{67}$

\footnotetext{
${ }^{65}$ Amir Syarifuddin, Ushul Figh 2..., p. 268.

${ }^{66}$ Amir Syarifuddin, Ushul Fiqh 2..., p. 267.

67 Shubhi Sulaiman, al-Thibbun Nabawi, (Istambul 2015 M/1436 H), p. 95.
} 
In more detail, the middle in eating and drinking is clearly seen in the hadith of the Prophet Muhammad:

"From Yahya bin Jabir Ath-Thoi said: I heard Rasulullah PBUH, said: "Man does not fill a nasty container beyond the stomach, it is enough for a man a few mouthfuls to straighten his backbone, otherwise one third is for his food, a third is for his drink and a third is for his breath. (Narrated by Al-Tirmidzi). ${ }^{68}$

After analyzing or paying attention to Ibn Qayyim's thoughts which are still guided by the verses of the Quran and the hadiths above, it is possible to understand how to interpret the law from the arguments about maintaining health as outlined in al-Thibb al-Nabawi. Ibn Qayyim Al-Jauziyah in wrote law using the method of ijtihâd which he used in understanding the Quran and Sunna of the Prophet, not with the knowledge of Ushûl Fiqh directly. This is only a way of understanding the verse. There are many ways to designate verses for a particular madlul, there are dilâlah 'ibârah or ibâratun nash, isyâratun nash or also called dilâlah isyarah, and dilâlatun nash or dilâlah al-dilâlah. ${ }^{69}$ This method was widely used by Ibn Qayyim, to a conclusion that had never been concluded by other scholars, even though his level of knowledge was higher than that of Ibn Qayyim. ${ }^{70}$

Health and safety are God's blessings of the highest value, and His most noble gift. Even salvation is the absolute greatest gift. It is proper for people who are given the convenience, to maintain and to protect it from everything that damages it. ${ }^{71}$ Rasulullah PBUH, once said:

"From Ibn Abbas radliallahu 'anhuma he said; Prophet Muhammad once stated: "Two pleasures that most people often forget are health and leisure."72 (Narrated by Bukhari)

According to Ibn Qayyim, it is on this basis that some Salaf scholars are based ${ }^{73}$, this is what

\footnotetext{
${ }^{68}$ Ibnu Qayyim Al-Jauziyyah, Al-Thibbun Nabawi..., p. 19.

${ }^{69}$ Amir Syarifuddin, Ushul Figh 2..., p. 148 and Interview, Padang, September 15, 2019.

${ }^{70}$ Amir Syarifuddin, Interview, Padang, March 9, 2019.

${ }^{71}$ lbid.

${ }^{72}$ HR. Bukhari (Lidwa Pusaka i-SoftwareKitab 9 Imam Hadis, Hadis No. 5933). see Ibnu Qayyim Al-Jauziyah, Mukhtashar Zadul Ma'ad, p. 394 or Ibnu Qayyim Al Jauziyah, Al-Thibbun Nabawi Metode Pengobatan Nabi, p. 269.

73 Ibnu Qayyim Al-Jauziyah, Al-Thibbun Nabawi..., p.147.
}

Allah Swt means in Al-Takasur[102] verse 8:

"Then you will certainly be asked on that day about pleasure" (which you boasted in that world).

In Musnad of Imam Ahmad it is narrated from the Prophet that he once said to Abbas, "O Abbas, O uncle of the Prophet! Ask for health and affinity in this world and the hereafter." 74 Another narration from Abu Bakr Ash-Siddiq that he told me that I had heard Rasulullah SAW said:

"From Yunus from Al Hasan that Abu Bakr was speaking before people, then he said; Rasulullah SAW said: "O people, in fact in this world humans are not given anything better than belief and salvation, so ask Allah for both..." (Narrated by Ahmad)75

In this narration the two forms of salvation are combined, the world and the hereafter. Because the benefit of a servant in this world and the hereafter will not be perfect except with faith and afiat (salvation). Faith will be able to spare humans from various torments in the hereafter. While salvation means freeing oneself from various forms of world disease, heart disease or physical disease. ${ }^{76}$

Likewise in understanding health, he is guided by dilâlah 'ibârah or 'ibâratun nash, as a legal istinbâth from the word of Allah in al-Syu'ara '[25] verse 88-89:

"(i.e.) in the day wealth and sons are useless, except those who turn to Allah with a clean heart"

The meaning of the word salim in the above verse is healthy. The Quran uses this word, because it is an adjective such as al-thawil (long), al-qashîr (short), al-dzarîf (beautiful and charming). So a healthy heart is a healthy heart that has become its characteristic and is attached to it, like the words al-'Aalîm (who knows), and al-qadîr (capable). In addition, the word salîm is the opposite of the word al-marîdh (sick). ${ }^{77}$

74 Ibnu Qayyim Al-Jauziyah, Al-Thibbun Nabawi..., p.147. see Ahmad hadits (Lidwa Pusaka i-SoftwareKitab 9 Imam Hadis, Hadis No. 1673).

75 Ibnu Qayyim Al-Jauziyah, Al-Thibbun Nabawi..., p.147. see Ahmad hadits (Lidwa Pusaka i-SoftwareKitab 9 Imam Hadis, Hadis No. 37).

${ }^{76}$ Ibnu Qayyim Al-Jauziyah, Al-Thibbun Nabawi..., p. 148.

77 Ibnu Qayyim Al-Jauziyah, Risalatu fi Amradhil Qulubi, 
Furthermore, Ibn Qayyim argued with the word of Allah in an-Nisa '(4) verse 43:

"And if you are sick or traveling or come from a place to defecate or you have touched a woman, then you do not get water, then replace it with good (holy) soil."

The conclusion of the verse, said Ibn Qayyim, a sick person is allowed to replace water with dust for purification, in order to maintain his body for health, in order to avoid harmful elements. ${ }^{78} \mathrm{lbn}$ Qayyim explained specifically about health, and its maslahah based on istiqra' (empirical research). This is used for the attitude of maintaining the health of the body from the outer and inner elements (physical and psychological). Through this method, the flexibility of Islamic law is very clear, that Islamic law can protect the development of times and places, including through its mashlahah. One of the principles of fostering Islamic law is maintaining benefit, however that benefit should not conflict with the texts. If it contradicts the text, then the text takes precedence, and the maslahah that is contrary to the text is called al-mashlahah al-mulghah. ${ }^{9}$

Regardless of the development of times, places, and the environment, Muslims will experience constraints and difficulties, while Islamic law seeks to remove all forms of narrowness and difficulties from people, because Islamic law was revealed for the benefit of mankind. This includes the mashlahah method, Al-Syatibi defined the mashlahah from two views, namely in terms of the occurrence of mashlahah in reality and from depending on the demands of syara' on mashlahah. In terms of the occurrence of mashlahah in reality, it means: "Something that returns to the uprightness of human life, is perfect in life, achieves what is desired by the nature of syahwat and its absolute origin." Meanwhile, in terms of the dependence of syara' demands on mashlahah, namely benefits which is the goal of establishing syara' law. In order to produce it, humans must act. ${ }^{80}$

\footnotetext{
translated by Fadhli Bahri Lc, (Jakarta: Pustaka Azzam, 2002), p.17.

${ }^{78}$ Ibnu Qayyim Al-Jauziyah, Al-Thibbun Nabawi..., p.122.

79 Suansar Khatib, "Metode ljtihad Ibrahim Hosen", Jurnal Ilmiah Mizani, vol. 2, no.1 (2015), p. 67.

${ }^{80}$ Amir Syarifuddin, Ushul Figh 2..., p.325.
}

Meanwhile, according to Al-Thufi, as quoted by Amir Syarifuddin defines mashlahah as "an expression of the causes that lead to the goal of syara" in the form of worship or custom." ${ }^{81}$ Furthermore, Amir Syarifuddin said that the definition of al-Thufi is in accordance with the definition of Imam al-Ghazali who views mashlahah in the sense of syara' as something that can lead to the goals of syara'. From several definitions of mashlahah with different formulas, it can be concluded that mashlahah is something that is considered good by common sense because it brings goodness and avoids badness (damage) for humans, in line with syara' goals in legal istinbâth.

From this conclusion, it can be seen that there is a difference between mashlahah in the sense of language (general) and mashlahah in the sense of law or syara'. The difference can be seen from the goal of syara' which is used as a reference. Mashlahah in the sense of language refers to the purpose of meeting human needs and therefore implies not following lust. Whereas mashlahah in the sense of syara' which is the point of discussion in ushûl figh, which is always the measure, and reference is the goal of syara', which is to maintain religion, soul, mind, descent and property, without giving up the goal of fulfilling human needs, namely getting pleasure and avoiding discomfort. ${ }^{82}$

In his book al-Thuruq al-Hukmiyyah fî al-Siyâsah al-Syar'iyyah, when discussing the al-siyâsah alsyar'iyyah, Ibn Qayyim said that an action must always refer to the benefit of humans and prevent them from being inconsolable, even if actions are neither specifically determined by Allah through revelation, nor are it determined by the Messenger of Allah through his Sunna, on condition that it does not differ from those determined by syara'. ${ }^{83}$

It can be emphasized that the istinbâth used by Ibn Qayyim is to understand the Quran in several ways, including: first, understanding dilâlah 'ibârah or 'ibâratun nash which is written

\footnotetext{
${ }^{81}$ Amir Syarifuddin, Ushul Figh 2..., p.326.

${ }^{82}$ Amir Syarifuddin, Ushul Figh 2..., p. 326.

${ }_{3}^{3}$ Ibnu Qayyim Al-Jauziyah, At-Turuq al-Hukmiyyah fi asSiyaasah Asy-Syar'iyyah, (Kairo: al-Mu'assasah al-'Arabiyyah li atTibaa'ah wa an-Nasyr, 1961), p. 285-310 quoted from Nasrun Haroen, "ljtihâd Ibnu Qayyim Al-Jauziyah Dalam Konteks Perubahan Sosial”, Disertasi, Pascasarjana IAIN Syarif Hidyatullah, Jakarta 1996, p. 205.
} 
directly in the Quran; second, with 'isyâratun nash, it does not address medication and health, it is not written but the verse implies; third, dilâlatun nash, namely dilâlah lafaz of the law that is discussed for something that is not mentioned, because it can be understood that there is a connection based on the understanding of the language..$^{84}$

\section{Consclusion}

Based on the description above, it can be concluded that the method of Ibn Qayyim's legal istinbâth which is derived from the Quran and hadiths on medicine and health, mostly used the understanding of lafadz with the method of dilalah 'ibârah or also known as ibâratun nash, which is the meaning that can be understood from what is directly mentioned in lafadz either in the form of text or zahir. Apart from that, it is also used isyâratun and dilâlatun nash, especially for the law of a case which is not explicitly stated, but the law can be understood because of its relationship from the perspective of linguistic understanding. The relevance of Ibn Qayyim's method of legal istinbâth with the theory of medication and health in recent human life, the point is that it appears in Q.S. Al-Syu'ara' '[26] verse: 80 , that in Islamic law it is obligatory to believe that every disease has a medicine and can be cured with the permission of Allah. Because it is required to pray to Allah, and to eat good/halal thayyiban food. In addition, regarding therapy related to the process of medical action, it must be preceded by maintaining a healthy body through preventive measures, and carrying out the process of expelling substances in the body that receive a mixture of harmful substances, including by reading the Quran more in jahr (by voice).

\section{References}

Aswar, "Strategi Terapiutik Korban Homoseks: Studi Terhadap Pemikiran Ibnu Qayyim alJauziyah", Islamic Counseling: Jurnal Bimbingan dan Konseling Islam, vol. 4, no. 2, 2020.

Andiko, Toha, Fiqh Kontemporer, Bogor: IPB Press, 2014, $1^{\text {st }}$ edition. 2019.

${ }^{84}$ Amir Syarifuddin, Wawancara, Padang, September 15 ,
Effendi, Satria, Ushûl Fiqh, Jakarta: Kencana, 2008. Hammam, Hasan Bin Ahmad and Tim Darul Hadharah, Terapi dengan Ibadah, Solo: Aqwam, 2015.

Jauziyyah, Ibnu Qayyim Al-, Al-Fawa'id, translated by Dzul hikmah, Jakarta: Qisthi Press, 2015. , Al-Taubah Wa al-Inabah, translated by Ahmad Dzulfikar, Jakarta: Qisthi Press, 2012. , Al-Thibb al-Nabawi, Beirut: Dar al-Kutub al-Ilmiyyah, 2002M/1423H. At-Thibbun Nabawi Metode Pengobatan Nabi, Pentahqiq: Abdul Ghani Khaliq, Penta'li: Adil Al-Azhari, Pentakhrij: Mahmud Farraj AlUqdah, Jakarta: Griya Ilmu,1435 H/2014 M. Fawaidul Fawaid, Menuju Pribadi Taqwa, translated by Munirul Abidin, Jakarta: Pustaka Al-Kautsar, 2016.

, Ighatsatul Lahfan min Mashâidisy Syaitân, translated by Hawin Murtadha \& Salafuddin Abu Sayyid, Sukoharjo: Al-Qawam, 2017.

, Manhaj Tarbiyah Ibnu Qayyim, translated by Muzaidi Hasbullah, Jakarta: Al Kautsar, 2001. , Mukhtashar Zadul Ma'ad, Jakarta: AlI'tisham, 2016.

, Rahasia Pengobatan Nabi saw, Ed. Muhammad Khathib, Jakarta: Mitrapress, 2013.

, Terapi Penyakit Hati, translated by Salim Bazemool, Jakarta: Qisthi Prees, 2017, $1^{\text {st }}$ print.

, Ad-Da'u wa ad-Dawa' (Terapi Penyakit Hati), translated by Salim Bazemol, Jakarta: Qisthi Press, 2017.

, At-Turuq al-Hukmiyyah fi as-Siyaasah AsySyar'iyyah, Kairo: al-Mu'assasah al-'Arabiyyah li at-Tibaa'ah wa an-Nasyr, 1961.

Khatib,Suansar, "Metode ljtihad Ibrahim Hosen", Jurnal Ilmiah Mizani, vol. 2, no.1, 2015.

Khudlâri Bek, Muhammad, Ushûl al-Fiqh, Beirut: Dâr al-Fikr, 1969.

Lbs, Junaidi,"Elastisitas Hukum Islam Dalam Merespons Perubahan Sosial, Madania, Vol. xviii, No. 1, Juni 2014.

Nurhayati, "Kesehatan dan Perobatan dalam Tradisi Islam: Kajian Kitab Shahih al-Bukhârî", Ahkam, vol. XVI, no. 2, Juli 2016.

Putra, Sakha Meindra, Isep Zaenal Arifin, Siti Chodijah, "Terapi Penyakit Maksiat Menurut Ibnu Al-Qayyim Al-Jauziyyah”, Irsyad: Jurnal 
Bimbingan, Penyuluhan, Konseling, dan Psikoterapi Islam, vol. 7, no.4, 2019.

Rochman, Kholilur, "Terapi Penyakit Hati Menurut ibn Taimiyah dalam Perspektif Bimbingan Konseling Islam", KOMUNIKA, vol.3 no.2 JuliDesember 2009.

Sa'id, Hammad, Al-Ilaj bil 'Asl, At-Tadawi bil Ma', Al-Ilaj bin Tamr, At-Tadawi bi Zait Zaitun, Penerjemah: Ahmad Syakirin, Kedokteran Nabi, Solo: Aqwamedika, 2014.
Syaifuddin, Amir, Ushûl Fiqh Jilid 1 dan 2, Jakarta: Logos Wacana Ilmu, 2011.

Yasin, M. Nu'aim, Fikih Kedokteran, Trans. Munirul Abidin, Jakarta: Pustaka Al-Kautsar, 2006. Zaki, Jamal Muhammad Az-, Thibbu al-lbadat, Trans. Shalahuddin, Hidup Sehat Tanpa Obat (Manfaat Medis dalam Ibadah Shalat, Puasa, Zakat dan Haji), Jakarta: Cakrawala Publishing, 2013. 